\title{
Epidemiological survey of workers exposed to cobalt oxides, cobalt salts, and cobalt metal
}

\author{
Bert Swennen, Jean-Pierre Buchet, Dan Stánescu, Dominique Lison, Robert Lauwerys
}

\begin{abstract}
Several organs (lung, skin, thyroid, heart, bone marrow) are potential targets of cobalt (Co). Whereas there is no doubt that inhalation of Co alone may cause bronchial asthma, its role in the occurrence of hard metal disease is still controversial because most cases were reported in workers exposed not only to Co but also to other substances such as tungsten carbide, titanium carbide, iron, silica and diamond. To assess whether exposure to pure Co dust (metal, oxides, or salts) may lead to adverse health effects a cross sectional study was carried out among 82 workers in a Co refinery. The results were compared with those in a sex and age matched control group. The Co group had been exposed for $8 \cdot 0$ years on average (range $0 \cdot 3-39 \cdot 4$ ). The geometric mean time weighted average exposure assessed with personal samplers $(n=82)$ was about $125 \mu \mathrm{g} / \mathrm{m}^{3}$ and $25 \%$ of the values were higher than $500 \mu \mathrm{g} / \mathrm{m}^{3}$. The concentrations of Co in blood and in urine after the shift were significantly correlated with those in air. Concentration of $\mathrm{Co}$ in urine increased during the workweek. A slight interference with thyroid metabolism (decreased T3, T4, and increased TSH), a slight reduction of some erythropoietic variables (red blood cells, haemoglobin, packed cell volume) and increased white cell count were found in the exposed workers. The exposed workers complained more often of dyspnoea and wheezing and had significantly more skin lesions
\end{abstract}

Medical Department, Union Minière, Olen, Belgium

B Swennen

Industrial Toxicology and Occupational Medicine Unit, School of Medicine, Catholic University of Louvain, Brussels, Belgium

J P Buchet, D Lison, R Lauwerys

Pulmonary Laboratory and Division, Cliniques Universitaires St Luc, Catholic University of Louvain, Brussels, Belgium

D Stánescu (eczema, erythema) than control workers. Within the exposed group a dose-effect relation was found between the reduction of the forced expiratory volume in one second/vital capacity and the intensity of current exposure to Co assessed by the measurement of $\mathrm{Co}$ in air or in urine. The prevalence of dyspnoea was related to the dustiness of the workplace as reflected by a statistically significant logistic regression between this symptom and the current levels of $\mathrm{Co}$ in air and in urine. No difference between lung volumes, ventilatory performances, carbon monoxide diffusing capacity, and serum myocardial creatine kinase and procollagen III peptide was found between the Co and control groups and no lung abnormalities were detected on the chest radiographs in both groups. The results suggest that exposure to high airborne concentrations of Co alone is not sufficient to cause pulmonary fibrosis. This finding is compatible with experimental studies indicating that interaction of other airborne pollutants with Co particles play a part in the pathogenesis of parenchymal lung lesions.

(British fournal of Industrial Medicine 1993;50:835-842)

Excessive exposure to Co compounds has been associated with adverse effects in several organs (skin, lung, thyroid gland, myocardium, bone marrow). In occupational settings, the respiratory tract is the main target organ. ${ }^{1}$

There is ample evidence that exposure to Co dust, alone or in association with other substances, may cause bronchial asthma. ${ }^{2-5}$ The symptoms (wheezing, chest tightness, dyspnoea, cough) usually improve after removal from exposure. A type I allergic reaction has been postulated, because specific IgE antibodies against a complex of Co with albumin can sometimes be detected. ${ }^{6}$ This, however, does not exclude a non-specific irritative action of Co on the bronchial tree. ${ }^{3}$ The incidence of bronchial asthma induced by $\mathrm{Co}$ is low (5\%).

Another pulmonary disease, also associated with 
exposure to dust containing $\mathrm{Co}$, is the so called "hard metal disease", an interstitial lung disease ranging from alveolitis to pulmonary fibrosis. It has the typical clinical features of a progressive interstitial lung disease: dry cough, dyspnoea during exercise and subsequently at rest, weight loss, and cyanosis. In the later stages cor pulmonale may develop. Lung function tests reveal reduced lung volumes and diffusing capacity. Chest radiographs often show fine or course linear and/or round opacities. $^{34}$ 7-10

Since the first report by Jobs and Ballhausen in 1940,11 it has often been questioned whether Co alone is responsible for this particular disease. ${ }^{12}$ Several animal experiments with Co metal and salts have failed to reproduce the typical pulmonary lesions found in humans. ${ }^{13-15}$

It is also important to note that most cases of interstitial disease were described in hard metal and diamond polishing industries, where workers are exposed not only to Co metal powder but also to other constituents such as tungsten carbide, titanium carbide, diamond particles etc. ${ }^{2} 39$ 16-19

The few studies so far carried out in Co refineries, where exposure is to pure Co dust, never identified typical cases of interstitial disease. ${ }^{20} 21$

Therefore, to evaluate whether exposure to pure Co dust may lead to adverse health effects, a cross sectional health survey was carried out in a Co refinery in Belgium. At the same time, an environmental and biological monitoring programme was set up to characterise exposure to Co.

\section{Subjects and methods \\ STUDY POPULATION}

The Co plant, which is part of a large metallurgical concern, uses a wide variety of raw materials, mainly Co metal cathodes and scraps. These materials are dissolved in acid, sometimes after a preliminary treatment such as ball milling. The Co solution is then subjected to several hydrometallurgical purification steps. Various Co salts, oxides, and fine Co metal powders are obtained as final products. Several steps involve the manipulation of powdered material that generates dust. The exposed group included 82 male workers from the Co plant who had not suffered from lung diseases before employment or had never been occupationally exposed to other pneumotoxic chemicals.

A group of 82 age matched control workers not exposed to lung irritants was recruited in the mechanical workshops of a nearby plant belonging to the same company. Because both plants are located in the same area and apply similar hiring criteria and occupational health programmes an efficient matching between the Co and control groups was achieved for educational and socioeconomic state.
CLINICAL EXAMINATION AND TESTS OF LUNG FUNCTION

Each participant was asked to complete a slightly modified European Coal and Steel Community (ECSC) questionnaire on chronic bronchitis. Detailed information was collected on occupational history, respiratory complaints, and smoking habits. The worker was then submitted to a routine clinical examination.

Vital capacity (VC), forced expiratory volume in one second $\left(F E V_{1}\right)$, peak expiratory flow (PEF), and maximal expiratory flow rate at $75\left(\mathrm{MEF}_{75}\right)$ and $50\left(\mathrm{MEF}_{50}\right) \%$ of VC were measured with a rolling seal spirometer (Volugraph, Mijnhardt). Total lung capacity (TLC) and residual volume (RV) were estimated by the helium dilution method. Measurement of carbon monoxide diffusing capacity (TLCO) was performed by the single breath technique ${ }^{22}$ in a seated position with the Mijnhardt Diffusimat 2000. For each subject, the results were also expressed as percentages of the predicted values, which were calculated on the basis of age, weight, and height. The prediction equations were obtained from the following sources: Jouasset ${ }^{23}$ for static and dynamic lung volumes; Bass ${ }^{24}$ for maximal expiratory flow rates; Frans $e t a l^{25}$ for lung diffusing capacity.

A full size chest radiograph was interprete blindly by two independent readers who were conse sultants in radiology.

\section{BIOLOGICAL ANALYSES}

Venous blood and a spot urine sample were collected before and after the shift on Monday and Friday for Co determination. The blood sample withdrawn on Monday morning was also used for the other biological analyses. Routine haematological analyses-namely, red blood cell count (RBC), white blood cell count (WBC), haemoglobin ( $\mathrm{Hb})$, haematocrit (Htc), mean corpuscular volume (MCV), mean corpuscular haemoglobin (MCH), mean corpuscular haemoglobin concentration (MCHC), and platelet count were performed on a Coulter Counter (S5 model).

Total T3, T4, TSH, and T3 uptake were analysed by radioimmunoassay with the kits purchased from Monobind (Costa Mesa, CA, USA).

Myocardial creatine kinase (CPK) activity in serum was determined with the CK-MB (NAC- N act) Monotest from Boehringer Diagnostica (Mannheim, Germany). The procollagen III peptide (PC-III-P) was determined with the radioimmunoassay- gnost P-III-P from Behringwerke AG (Marburg, Germany). The concentrations of Co in whole blood and in urine were determined by flameless atomic absorption spectrometry with a Perkin-Elmer 5000 Zeeman spectrometer. Urinary 
Table 1 Characteristics of the study population

\begin{tabular}{|c|c|c|c|c|c|c|}
\hline & \multicolumn{3}{|l|}{ Control group } & \multicolumn{3}{|l|}{ Exposed workers } \\
\hline & $\begin{array}{l}\text { Non-smokers } \\
(n=31)\end{array}$ & $\begin{array}{l}\text { Smokers } \\
(n=51)\end{array}$ & $\begin{array}{l}\text { Total } \\
(n=82)\end{array}$ & $\begin{array}{l}\text { Non-smokers } \\
(n=23)\end{array}$ & $\begin{array}{l}\text { Smokers } \\
(n=59)\end{array}$ & $\begin{array}{l}\text { Total } \\
(n=82)\end{array}$ \\
\hline $\begin{array}{l}\text { Aget }(y) \\
\text { Duration of }\end{array}$ & $\mathrm{L}^{31 \cdot 0(19-56) \pi}$ & $\begin{array}{l}40 \cdot 0(20-55) \\
-\end{array}$ & $\mathrm{C}^{38 \cdot 0(19-56)}$ & $\begin{array}{r}32.0(20-58) \\
6.6(0.4-39.4)\end{array}$ & $\begin{array}{l}33 \cdot 0(19-58) \\
8 \cdot 2(0 \cdot 3-31 \cdot 2)\end{array}$ & $\begin{array}{l}33 \cdot 0(19-58) \\
8 \cdot 0(0 \cdot 3-39 \cdot 4)\end{array}$ \\
\hline $\begin{array}{l}\text { exposuref (y) } \\
\text { Height }(\mathrm{cm}) \\
\text { Weight }(\mathrm{kg}) \\
\text { Pack-yearst }\end{array}$ & $\begin{array}{l}177 \cdot 2(164-190) \\
76 \cdot 3(55-105) \\
-\end{array}$ & $\begin{array}{c}175 \cdot 0(164-189) \\
78 \cdot 0(59-127) \\
12(1-61)\end{array}$ & $\begin{array}{l}175 \cdot 8(164-190) \\
77 \cdot 3(55-127) \\
-\end{array}$ & $\begin{array}{l}174 \cdot 1(163-183) \\
78 \cdot 8(62-98) \\
-\end{array}$ & $\begin{array}{c}175 \cdot 2(160-199) \\
73 \cdot 6(54-120)^{\star} \\
9(1-78)\end{array}$ & $\begin{array}{l}174 \cdot 9(160-199) \\
75 \cdot 0(54-120) \\
-\end{array}$ \\
\hline
\end{tabular}

*Significantly different from the control group ( $t$ test: $p<0.05)$

tmedian; łgeometric mean; §arithmetic mean; Irange.

creatinine concentration was measured according to Jaffé's picrate method.

\section{AIR SAMPLING AND ANALYSES}

The exposure of each worker to airborne Co (total dust) was characterised by personal sampling. The Co concentration was determined in the breathing zone of the workers with a CIP10 dust sampler (MSA, Saint-Ouen-L'Aumône, France) equipped with two 45 grade and one 60 grade polyurethane foam filters. Air was sampled at a mean flow rate of $10 \mathrm{l} / \mathrm{min}$ for six hours. For each Co worker two measurements were made (on Monday and on Friday). After dissolution in a $10 \%$ sulphuric acid and $1 \%$ nitric acid solution, the Co content of the filters was determined by flameless atomic absorption spectrometry (Perkin Elmer, Zeeman 5000).

\section{STATISTICAL ANALYSIS}

Statistical analyses were by SAS procedures (SAS Institute). When variables were not normally distributed analysis was performed on log transformed data; non-parametric tests were used when log transformation did not normalise the distributions. A p value of $\leqslant 0.05$ was considered as the criterion of statistical significance.

\section{Results}

\section{POPULATION CHARACTERISTICS}

Table 1 summarises some characteristics of the control workers and those exposed to Co. The exsmokers were combined with the smokers. The Co group had been exposed to Co metal and Co salts for 8.0 years on average (range 0.3 to 39.4 ). Both populations were well matched for age, height, and smoking habits. The mean weight of the control smokers was slightly higher than that of smokers in the exposed group.

\section{ENVIRONMENTAL AND BIOLOGICAL EXPOSURE VARIABLES}

Figure 1 gives the results of the current airborne Co determinations performed by personal sampling (total dust) during two days. The geometric mean time weighted average exposure (TWA) was not significantly different at the beginning and at the end of the week. These data are representative of the usual exposure of the workers. About $70 \%$ of the workers were exposed to a TWA higher than the current American Conference of Governmental Industrial Hygienists' (ACGIH) TLV $\left(50 \mu \mathrm{g} / \mathrm{m}^{3}\right)$ and about $25 \%$ were exposed to a TWA higher than $500 \mu \mathrm{g} / \mathrm{m}^{3}$

Figures 2 and 3 present the cumulative frequency distribution of Co in urine and in blood of the exposed workers before and after the shift on Monday and Friday. Concentrations of $\mathrm{Co}$ in urine increased during the shift (the difference between the post and preshift geometric mean concentrations was to about $30 \mu \mathrm{g} / \mathrm{g}$ creatinine) and also during the workweek. The cumulative frequency distribution of the preshift values were significantly different $\left(\chi^{2}, \mathrm{p}<0.05\right)$ on Monday and Friday. Although the concentrations of $\mathrm{Co}$ in blood followed a similar pattern as Co in urine during the

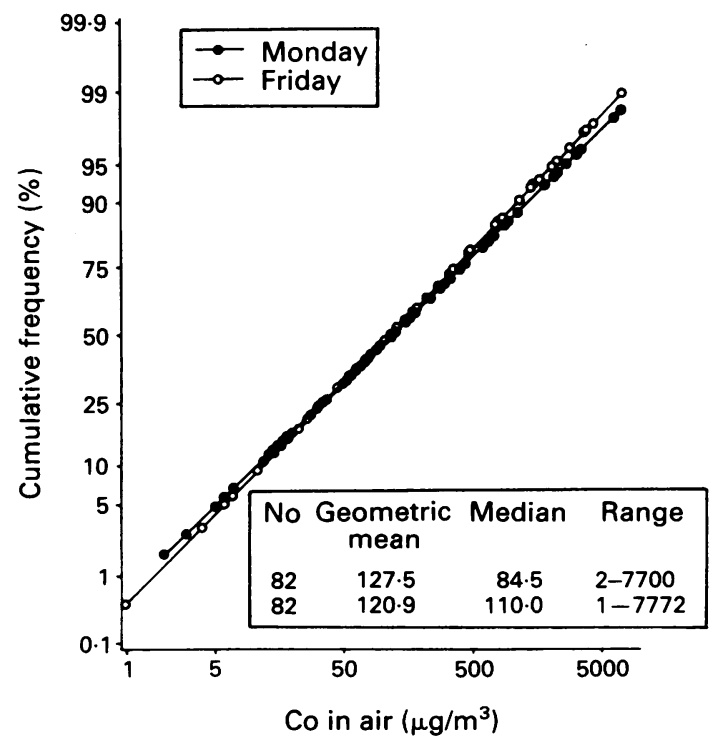

Figure 1 Cumulative frequency distribution of time weighted average concentration of airborne Co dust collected with personal sampling. 


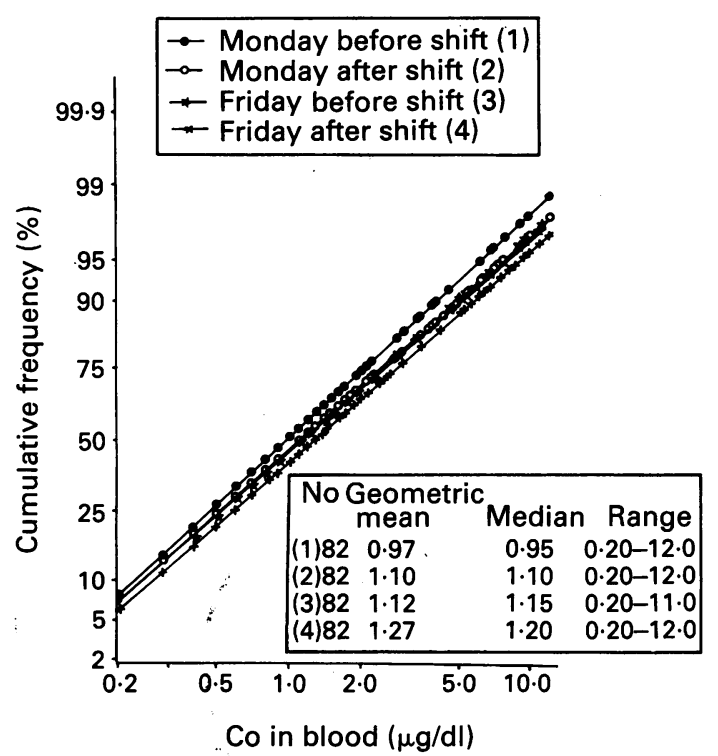

Figure 2 Cumulative frequency distribution of Co concentration in urine.

workshift and the week, the relative changes in concentrations were less than for urine. Concentrations of Co in urine (postshift sample) and in blood were correlated with Co in air both on Monday and on Friday $(r=0.72$ and 0.61 for urine and $r=0.64$ and 0.60 for blood respectively $p<0.001$ ).

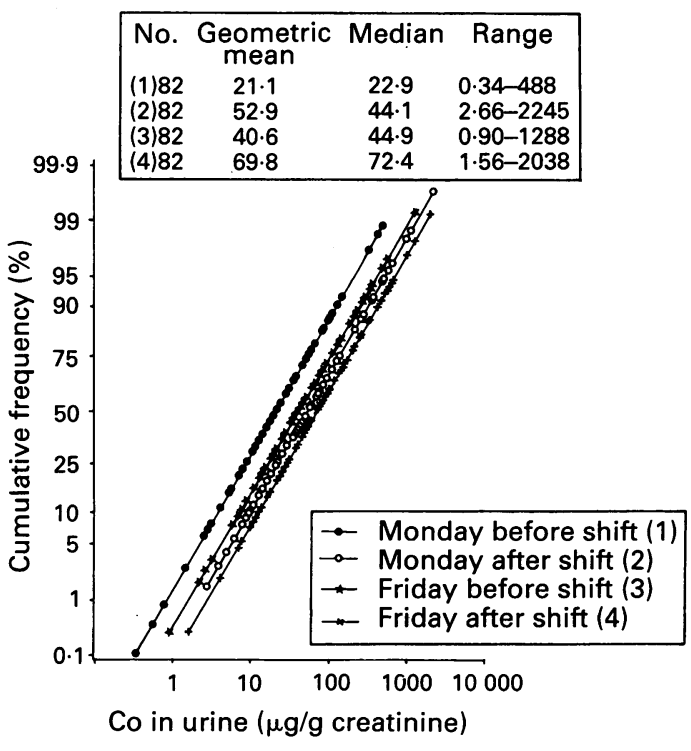

Figure 3 Cumulative frequency distribution of Co concentration in blood.

In control workers all the results of Co in urine and Co in blood were below $2 \mu \mathrm{g} / \mathrm{g}$ creatinine and $0.2 \mu \mathrm{g} / \mathrm{dl}$ respectively. A few determinations of $\mathrm{Co}$ in air were performed in the control plant. All the results were below $0.05 \mu \mathrm{g} / \mathrm{m}^{3}$ confirming the absence of exposure to $\mathrm{Co}$ in the control group.

Table 2 Respiratory symptoms

\begin{tabular}{|c|c|c|c|c|c|c|}
\hline \multirow[b]{2}{*}{ Respiratory symptom } & \multicolumn{3}{|l|}{ Control group } & \multicolumn{3}{|c|}{ Exposed workers } \\
\hline & $\begin{array}{l}\text { Non-smokers } \\
(n=31)\end{array}$ & $\begin{array}{l}\text { Smokers } \\
(n=51)\end{array}$ & $\begin{array}{l}\text { Total } \\
(n=82)\end{array}$ & $\begin{array}{l}\text { Non-smokers } \\
(n=23)\end{array}$ & $\begin{array}{l}\text { Smokers } \\
(n=59)\end{array}$ & $\begin{array}{l}\text { Total } \\
(n=82)\end{array}$ \\
\hline $\begin{array}{l}\text { Cough in cold season: } \\
\text { Morning } \\
\text { Whole day } \\
\text { Whole day, } 3 \text { months a year }\end{array}$ & $\begin{array}{l}0(0.0) \\
1(3 \cdot 2) \\
0(0.0)\end{array}$ & $\begin{array}{l}4(7 \cdot 8) \\
2(3.9) \\
2(3.9)\end{array}$ & $\begin{array}{l}4(4 \cdot 9) \\
3(3 \cdot 7) \\
2(2 \cdot 4)\end{array}$ & $\begin{array}{l}2(8 \cdot 7) \\
3(13 \cdot 0) \\
1(4 \cdot 4)\end{array}$ & $\begin{array}{l}6(10 \cdot 2) \\
5(8 \cdot 5) \\
5(8 \cdot 5)\end{array}$ & $\begin{array}{l}8(9 \cdot 8) \\
8(9 \cdot 8) \\
6(7 \cdot 3)\end{array}$ \\
\hline $\begin{array}{l}\text { Sputum in cold season: } \\
\text { Morning } \\
\text { Whole day } \\
\text { Whole day, } 3 \text { months a year }\end{array}$ & $\begin{array}{l}0(0.0) \\
0(0.0) \\
0(0.0)\end{array}$ & $\begin{array}{l}4(7 \cdot 8) \\
2(3 \cdot 9) \\
3(5 \cdot 9)\end{array}$ & $\begin{array}{l}4(4 \cdot 9) \\
2(2 \cdot 4) \\
3(3 \cdot 7)\end{array}$ & $\begin{array}{l}4(17 \cdot 4)^{\star} \\
3(13.0) \\
2(8 \cdot 7)\end{array}$ & $\begin{array}{l}6(10 \cdot 2) \\
4(6 \cdot 8) \\
4(6 \cdot 8)\end{array}$ & $\begin{array}{c}10(12 \cdot 2) \\
7(8 \cdot 5) \\
6(7 \cdot 3)\end{array}$ \\
\hline $\begin{array}{l}\text { Dyspnoea: } \\
\text { During heavy exercise } \\
\text { During normal exercise } \\
\text { During light exercise } \\
\text { At rest }\end{array}$ & $\begin{array}{l}0(0 \cdot 0) \\
1(3 \cdot 2) \\
0(0 \cdot 0) \\
0(0 \cdot 0)\end{array}$ & $\begin{array}{l}1(2 \cdot 0) \\
1(2 \cdot 0) \\
1(2 \cdot 0) \\
0(0 \cdot 0)\end{array}$ & $\begin{array}{l}1(1 \cdot 2) \\
2(2 \cdot 4) \\
1(1 \cdot 2) \\
0(0 \cdot 0)\end{array}$ & $\begin{array}{l}2(8 \cdot 7) \\
2(8 \cdot 7) \\
1(4 \cdot 4) \\
0(0 \cdot 0)\end{array}$ & $\begin{array}{l}11(18 \cdot 7)^{\star} \\
8(13 \cdot 6)^{\star} \\
6(10 \cdot 2) \\
5(8 \cdot 5)^{\star}\end{array}$ & $\begin{array}{c}13(15 \cdot 9)^{\star} \\
10(12 \cdot 2)^{\star} \\
7(8 \cdot 5)^{\star} \\
5(6 \cdot 1)^{\star}\end{array}$ \\
\hline $\begin{array}{l}\text { Wheezing: } \\
\text { Ever } \\
\text { Daily }\end{array}$ & $\begin{array}{l}3(9 \cdot 7) \\
0(0 \cdot 0)\end{array}$ & $\begin{array}{l}6(11 \cdot 8) \\
0(0 \cdot 0)\end{array}$ & $\begin{array}{l}9(11 \cdot 0) \\
0(0 \cdot 0)\end{array}$ & $\begin{array}{l}2(8 \cdot 7) \\
0(0 \cdot 0)\end{array}$ & $\begin{aligned} 11(18 \cdot 6) \\
5(8 \cdot 5)^{\star}\end{aligned}$ & $\begin{array}{r}13(15 \cdot 9) \\
5(6 \cdot 1)^{\star}\end{array}$ \\
\hline $\begin{array}{l}\text { Rhinitis: } \\
\text { Daily, } 3 \text { months a year }\end{array}$ & $3(9 \cdot 7)$ & $5(9 \cdot 8)$ & $8(9 \cdot 8)$ & $1(4 \cdot 4)$ & $10(17 \cdot 0)$ & $11(13.4)$ \\
\hline $\begin{array}{l}\text { Hay fever } \\
\text { Acute bronchitis in past } 3 \text { years }\end{array}$ & $\begin{array}{l}1(3 \cdot 2) \\
1(3 \cdot 2)\end{array}$ & $\begin{array}{l}2(3 \cdot 9) \\
5(9 \cdot 8)\end{array}$ & $\begin{array}{l}3(3 \cdot 7) \\
6(7 \cdot 3)\end{array}$ & $\begin{array}{l}0(0 \cdot 0) \\
2(8 \cdot 7)\end{array}$ & $\begin{array}{l}3(5 \cdot 1) \\
7(11 \cdot 9)\end{array}$ & $\begin{array}{l}3(3 \cdot 7) \\
9(11 \cdot 0)\end{array}$ \\
\hline
\end{tabular}

${ }^{\star}$ Significantly different from the corresponding control group $\left(\chi^{2}, p<0.05\right)$.

Values are numbers of workers (\%). 
Table 3 Lung function tests

\begin{tabular}{|c|c|c|c|c|c|c|}
\hline \multirow[b]{2}{*}{ Test } & \multicolumn{3}{|l|}{ Control group } & \multicolumn{3}{|l|}{ Exposed workers } \\
\hline & $\begin{array}{l}\text { Non-smokers } \\
(n=31)\end{array}$ & $\begin{array}{l}\text { Smokers } \\
(n=51)\end{array}$ & $\begin{array}{l}\text { Total } \\
(n=82)\end{array}$ & $\begin{array}{l}\text { Non-smokers } \\
(n=23)\end{array}$ & $\begin{array}{l}\text { Smokers } \\
(n=58)\end{array}$ & $\begin{array}{l}\text { Total } \\
(n=81)\end{array}$ \\
\hline $\begin{array}{l}\text { FVC }(1)^{\star} \\
\operatorname{RV}(1) \dagger \\
\operatorname{TLC}(1)^{\star} \\
\operatorname{RV} / T L C(\%) \dagger \\
\operatorname{FEV}_{1}(1) \ddagger \\
\operatorname{FEV}_{1} / \mathrm{VC}(\%) \\
\operatorname{PEF}_{(1 / s)^{\star}} \\
\operatorname{MEF}_{75}(1 / s) \ddagger \\
\operatorname{MEF}_{50}(1 / s) \dagger\end{array}$ & $\begin{array}{c}5.23(93.17) \\
(3.76-6.62) \\
1.73(107 \cdot 30) \\
(1.06-3.00) \\
7.02(97.01) \\
(4.89-9.09) \\
24.95(112.05) \\
(16.86-34.84) \\
4.05(91.14) \\
(3.07-5.36) \\
82.48 \\
(63.89-94.23) \\
9.18(109 \cdot 27) \\
(5.50-12.80) \\
2.00(102 \cdot 15) \\
(1.00-4.10) \\
4.60(86.82) \\
(2.50-6.90) \\
39.70(117.10) \\
(25.85-51.00) \\
5.74(110.92) \\
(3.81-7.76)\end{array}$ & $\begin{array}{c}4.87(90.77) \\
(3.40-6.38) \\
1.97(119.45) \\
(1.08-3.36) \\
6.91(98.34) \\
(5.29-8.37) \\
28.78(121.49) \\
(17.91-45.40) \\
3.63(94.53) \\
(2.65-5.20) \\
84.69 \\
(60.18-92.53) \\
9.22(112.10) \\
(5.60-12.60) \\
1.80(99.33) \\
(0.70-5.00) \\
4.65(90.05) \\
(2.00-8.80) \\
35.34(109.17) \\
(25.80-59.45) \\
5.23(103.70) \\
(3.63-8.37)\end{array}$ & $\begin{array}{c}5.01(91.67) \\
(3.40-6.62) \\
1.88(114.70) \\
(1.06-3.36) \\
6.95(97.83) \\
(4.89-9.09) \\
27.27(117.84) \\
(16.86-45.40) \\
3.95(94.22) \\
(2.65-5.36) \\
83.51 \\
(60.18-94.23) \\
9.20(111.03) \\
(5.50-12.80) \\
1.85(99.70) \\
(0.70-5.00) \\
4.63(88.82) \\
(2.00-8.80) \\
36.99(112.16) \\
(25.80-59.45) \\
5.42(106.37) \\
(3.63-8.37)\end{array}$ & $\begin{array}{c}4.92(92.60) \\
(3.12-7.01) \\
1.57(99.50) \\
(0.92-3.41) \\
6.57(95.33) \\
(5.08-8 \cdot 13) \\
24.09(104 \cdot 86) \\
(13.78-52.22) \\
3.98(99 \cdot 17) \\
(2.46-5 \cdot 23) \\
83.91 \\
(74.06-91.88) \\
9.06(109.49) \\
(5.40-11.90) \\
2.00(111.09) \\
(1.20-3.50) \\
4.91(92.39) \\
(3.20-8.20) \\
38.00(116.83) \\
(26.75-46.55) \\
5.83(114 \cdot 18) \\
(4.87-7.42)\end{array}$ & 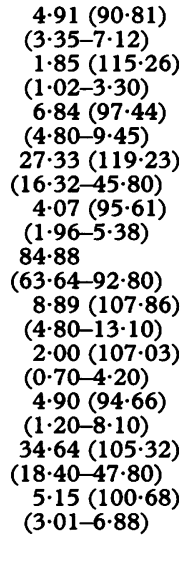 & 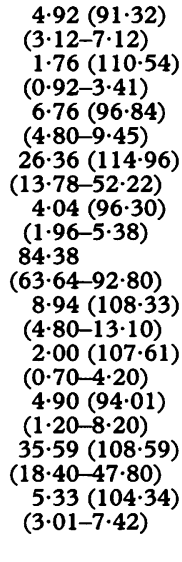 \\
\hline
\end{tabular}

*arithmetic mean; †geometric mean; łmedian, \% of predicted value and range in parentheses.

EFFECT VARIABLES QUESTIONNAIRE

The questionnaire on respiratory symptoms was analysed separately for smokers and non-smokers and for both groups combined (table 2). Dyspnoea during exercise and at rest and wheezing was more often reported by the exposed workers and especially by the smokers $\left(\chi^{2}, \mathrm{p}<0.05\right)$. No statistically significant interaction was found, however, between smoking and exposure to Co. These symptoms were mainly prevalent among workers occupied in the dry process of Co production. For the other symptoms, the analysis did not show any statistical difference between the control and Co groups.

\section{CLINICAL EXAMINATION AND TESTS OF LUNG}

FUNCTION

The clinical examinations detected more subjects with skin problems (eczema, erythema) (51\% v $25 \%, \mathrm{p} \leqslant 0.001)$ and wheezing $(16 \% v 6 \%, \mathrm{p}<$ $0.05)$ in the exposed than in the control group. No difference between control and Co groups was found for lung volumes, ventilatory performances, and single breath lung diffusing capacity (table 3 ). Likewise the prevalences of measurements of lung function (RV, TLC, RV/TLC (\%)) below the 5 or above the 95 percentile values of the control group were not significantly different between control and Co groups (results not shown).

No lung abnormalities were detected on the chest radiographs in both groups.

BIOLOGICAL VARIABLES

The thyroid hormone $\mathrm{T} 3$ and the erythropoietic variables (RBC, $\mathrm{Hb}, \mathrm{Htc}$ ) showed a statistically significant trend towards lower values in the Co group whereas WBCs were significantly higher (table 4).

The other measurements, particularly PC-III-P,

Table 4 Biological analyses

\begin{tabular}{|c|c|c|}
\hline Variable & $\begin{array}{l}\text { Control group } \\
(n=82)\end{array}$ & $\begin{array}{l}\text { Exposed workers } \\
(n=82)\end{array}$ \\
\hline T3 (ng/dl)t & $\begin{array}{l}150 \cdot 00 \\
(92 \cdot 00-207 \cdot 00) \rrbracket\end{array}$ & $\begin{array}{l}140 \cdot 18^{\star} \\
(82 \cdot 00-215 \cdot 00)\end{array}$ \\
\hline T3 uptake (\%) $\dagger$ & $(32 \cdot 20-55 \cdot 60)$ & $(29 \cdot 20-60 \cdot 10)$ \\
\hline T4 $(\mu \mathrm{g} / 1) \ddagger$ & $\begin{array}{l}79 \cdot 00 \\
(48 \cdot 00-111 \cdot 00)\end{array}$ & $\begin{array}{l}76 \cdot 00 \\
(19.00-118.00)\end{array}$ \\
\hline TSH & $\begin{array}{l}4.72 \\
(1.85-7.63)\end{array}$ & $4 \cdot 78$ \\
\hline TSH $(\mu \mathrm{IU} / \mathrm{ml}) \ddagger$ & $\begin{array}{l}(1 \cdot 85-7 \cdot 63) \\
9 \cdot 00\end{array}$ & $\begin{array}{l}(3 \cdot 33-9 \cdot 18) \\
8 \cdot 00\end{array}$ \\
\hline CPK (IU/I) $\ddagger$ & $(1 \cdot 00-18 \cdot 00)$ & $\begin{array}{l}(3 \cdot 00-18 \cdot 00) \\
7 \cdot 39\end{array}$ \\
\hline PC-III-P (ng/ml)‡ & $(4.57-11.95)$ & $\begin{array}{l}(1.39 \\
5.00\end{array}$ \\
\hline Sedimentation rate $(\mathrm{mm} / \mathrm{h}) \ddagger$ & $(1 \cdot 00-29 \cdot 00)$ & $\begin{array}{l}(1 \cdot 00-17 \cdot 00) \\
8.03 \star\end{array}$ \\
\hline WBC $\left(10^{9} / 1\right)$ & $(4 \cdot 1-11 \cdot 8)$ & $(4 \cdot 8-14 \cdot 8)$ \\
\hline $\operatorname{RBC}\left(10^{12} / 1\right) \dagger$ & $\begin{array}{l}5 \cdot 08 \\
(4 \cdot 49-5 \cdot 77)\end{array}$ & $\begin{array}{l}4 \cdot 85^{\star} \\
(3 \cdot 96-5 \cdot 49)\end{array}$ \\
\hline & 15.59 & $15 \cdot 05^{\star}$ \\
\hline $\mathrm{Hb}(\mathrm{g} / 100 \mathrm{ml}) \dagger$ & $\begin{array}{l}(12 \cdot 70-17 \cdot 50) \\
45 \cdot 54\end{array}$ & $\begin{array}{l}(13 \cdot 70-17 \cdot 50) \\
44 \cdot 03^{\star}\end{array}$ \\
\hline Htc $(\%) \dagger$ & $(40 \cdot 70-51 \cdot 10)$ & $(39 \cdot 50-50 \cdot 40)$ \\
\hline $\operatorname{MCV}(f) \ddagger$ & $(79 \cdot 00-97 \cdot 00)$ & $(84 \cdot 00-101 \cdot 00)$ \\
\hline & 31.00 & $31 \cdot 00$ \\
\hline MCH (pg)‡ & $(25 \cdot 00-34 \cdot 00)$ & $(28 \cdot 00-35 \cdot 00)$ \\
\hline $\operatorname{MCHC}(\mathrm{g} / 100 \mathrm{ml}) \ddagger$ & $(31 \cdot 00-36 \cdot 00)$ & $(33 \cdot 00-36 \cdot 00)$ \\
\hline Platelets $\left(10^{9} / 1\right) \dagger$ & $\begin{array}{l}239 \cdot 93 \\
(132.00-421 \cdot 00)\end{array}$ & $\begin{array}{l}247 \cdot 56 \\
(112 \cdot 00-390 \cdot 00)\end{array}$ \\
\hline
\end{tabular}

*Significantly different form the control group ( $t$ test. $p<0.05$ ). †Arithmetic mean; łmedian; §geometric mean; ๆrange; for abbreviations, see text. 
a potential biological marker of a fibrotic process, were not significantly different between the groups. The prevalences of abnormal values of T3, T4, TSH, CPK, WBC, and RBC were significantly higher in the Co workers than in the controls (table 5).

DOSE-EFFECT AND DOSE-RESPONSE RELATIONS

We have examined whether the intensity of the biological disturbance or the prevalence of abnormal biological results and respiratory complaints were associated with the intensity of exposure to Co (expressed in terms of Co in blood, Co in urine, Co in air, duration of exposure, and the product of duration of exposure with $\mathrm{Co}_{\mathrm{o}}$ in air or in urine). The results for RV and TLC (\% predicted values) were positively associated with duration of exposure (Pearson $r=0.40$ and 0.37 respectively; $p<$ 0.001) whereas the $\mathrm{FEV}_{1} / \mathrm{VC}$ ratio was negatively associated with current exposure variablesnamely, Co in urine and Co in air (Spearman $r$ between -0.25 and $-0.28, p \leqslant 0.01$ ). No significant dose-effect relations were found for the biological measurements. A logistic regression model was used to assess the probability of abnormal results as a function of the exposure variables. Only dyspnoea during exercise was found to be related to current concentrations of $\mathrm{Co}$ in air (figure 4) or in urine (results not shown).

\section{Discussion}

The present cross sectional epidemiological study compared male workers exposed to Co metal, Co oxides, and Co salts with a well matched control

Table 5 Biological analyses: prevalences of abnormal values

\begin{tabular}{|c|c|c|c|}
\hline Variable $\dagger$ & Cut-off value & $\begin{array}{l}\text { Control group } \\
(n=82)\end{array}$ & $\begin{array}{l}\text { Exposed workers } \\
(n=82)\end{array}$ \\
\hline $\begin{array}{l}\text { T3 } \\
\text { T3-UPTAKE } \\
\text { T4 } \\
\text { TSH } \\
\text { CPK } \\
\text { PC-III-P } \\
\text { WBC } \\
\text { RBC } \\
\text { Hb } \\
\text { Htc } \\
\text { MCV } \\
\text { MCH } \\
\text { MCHC } \\
\text { Platelets }\end{array}$ & $\begin{array}{l}<102 \cdot 20 \ddagger \\
>48 \cdot 88 \\
<57 \cdot 80 \\
>6 \cdot 16 \\
>12 \cdot 40 \\
>11 \cdot 10 \\
>9 \cdot 70 \\
<4.56 \\
>5 \cdot 69 \\
<13.54 \\
>17 \cdot 34 \\
<40.70 \\
>49.34 \\
<82.00 \\
>95 \cdot 00 \\
<27.40 \\
>33.00 \\
<32 \cdot 20 \\
>36.00 \\
<164 \cdot 20 \\
>351 \cdot 20\end{array}$ & $\begin{array}{l}1(1 \cdot 2) \S \\
4(4 \cdot 9) \\
2(2 \cdot 4) \\
3(3 \cdot 7) \\
3(3 \cdot 7) \\
2(2 \cdot 4) \\
8(9 \cdot 8) \\
5(6 \cdot 1) \\
2(2 \cdot 4) \\
1(1 \cdot 2) \\
3(3 \cdot 7) \\
2(2 \cdot 4) \\
6(7 \cdot 3) \\
1(1 \cdot 2) \\
9(11 \cdot 0) \\
1(1 \cdot 2) \\
7(8 \cdot 5) \\
2(2 \cdot 4) \\
7(8 \cdot 5) \\
4(4 \cdot 9) \\
2(2 \cdot 4)\end{array}$ & $\begin{array}{c}6(7 \cdot 3) \\
13(15 \cdot 9)^{\star} \\
15(18 \cdot 3)^{\star} \\
10(12 \cdot 2)^{\star} \\
10(12 \cdot 2)^{\star} \\
2(2 \cdot 4) \\
22(26 \cdot 8)^{\star} \\
13(15 \cdot 9)^{\star} \\
0(0 \cdot 0) \\
0(0 \cdot 0) \\
1(1 \cdot 2) \\
4(4 \cdot 9) \\
2(2 \cdot 4) \\
0(0 \cdot 0) \\
6(7 \cdot 3) \\
0(0 \cdot 0) \\
7(8 \cdot 5) \\
0(0 \cdot 0) \\
5(6 \cdot 1) \\
2(2 \cdot 4) \\
3(3 \cdot 7)\end{array}$ \\
\hline
\end{tabular}

*Significantly different from the control group $\left(\chi^{2} ; p<0.05\right)$.

$\dagger$ For units and abbreviations see table 4 and text; $\ddagger 5$ th or 95 th percentile value of the control group; łpercentage.

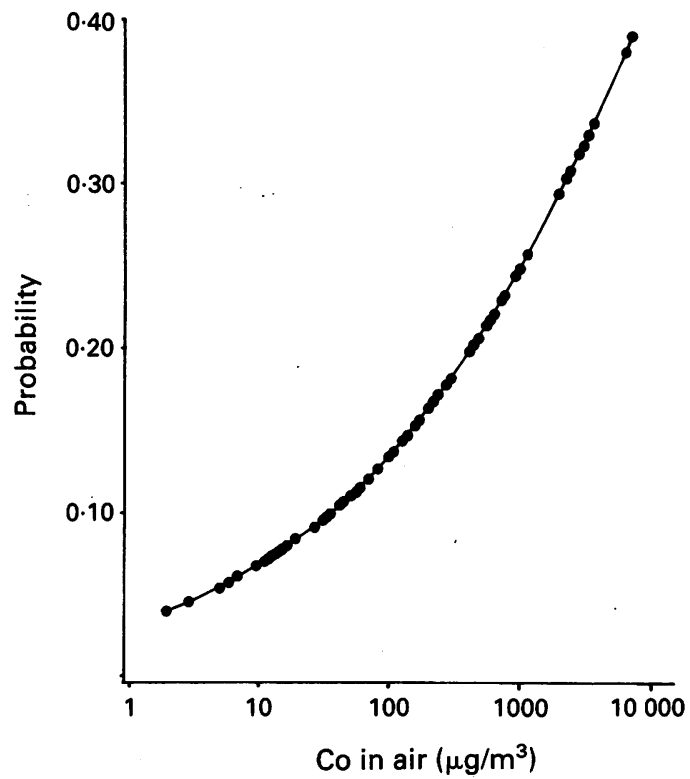

Figure 4 Probability of dyspnoea during exercise as a function of current airborne concentration of Co dust.

group. The workers were exposed for $8 \cdot 0$ years on average (range 0.3-39.4) to a mean airborne Coo concentration of $125 \mu \mathrm{g} / \mathrm{m}^{3}$ but for about $25 \%$ of the workers, the TWA exceeded $500 \mu \mathrm{g} / \mathrm{m}^{3}$. Exposure to Co was clearly reflected by an increase in the concentration of $\mathrm{Co}$ in urine at the end of the workshift. Although selection bias (healthy worker effect) cannot be formally excluded in the framework of a cross sectional study, it is unlikely that it may significantly affect our estimate because of the stability of the workforce in both plants. A slight interference with thyroid metabolism (decreased $\mathrm{T} 3, \mathrm{~T} 4$, and increased $\mathrm{TSH}$ ) was found in the exposed workers. Although no clinical case of hypothyroidism was found, this study suggests that Co may interfere with thyroid function. This result is in agreement with findings made in the past among patients treated with Co. ${ }^{26}$ At variance with the present results, increased concentrations of total and free serum T4 have been found in female Danish plate painters exposed to Co-zinc silicate (mean urinary Co concentration of $1.17 \mu \mathrm{g} /$ mmole creatinine). No significant effect on gland volume or serum TSH could be detected. ${ }^{27}$ In the present study, a few haematological variables were also significantly different between both groups. By contrast with previous animal experiments suggesting that administration of high doses of Co may cause polycythemia, ${ }^{28}$ the workers exposed to Co had a tendency to show a reduction in erythropoietic variables. We have no evident explanation for the 
increased WBC in exposed workers, which persists after standardisation for smoking habits. Animal experiments have also indicated that inhalation of Co could affect WBC. ${ }^{14}$ The haematological changes, however, were not dose related.

Two different respiratory syndromes involving either the bronchial tree or the lung parenchyma have been described among workers exposed to dust containing Co. Bronchial asthma has been clearly associated with exposure to Co. A bronchial provocation test with Co alone may induce acute bronchoconstriction. ${ }^{6}$ In this study, the exposed workers complained more often of dyspnoea and wheezing compared with a control group. The prevalence of dyspnoea was clearly related to the dustiness of the workplace as reflected by the statistically significant logistic regression between this symptom and the current concentrations of $\mathrm{Co}$ in air and urine. The lung auscultation also revealed an increased prevalence of wheezing in the exposed workers. Furthermore, a dose-effect relation was found between the reduction of the $\mathrm{FEV}_{1} / \mathrm{VC}$ ratio and the intensity of current exposure to $\mathrm{Co}$ as reflected by the concentration of Co in air and in urine. On the other hand, RV and TLC were positively correlated with the duration of exposure. Although the average lung function tests were not significantly different between the two groups, all these findings suggest an airway involvement in workers exposed to Co. The risk of respiratory complaints seems to be low when the exposure to Co alone does not exceed a TWA of $50 \mu \mathrm{g} / \mathrm{m}^{3}$ (fig 4). The results of other authors, however, suggest that when exposure is not to Co alone, an interaction between various components of the inhaled aerosol may lower the threshold effect level for the respiratory tract. Kusaka et $a^{3}$ found a $5 \%$ prevalence of occupational asthma among hard metal workers exposed to Co dust ranging from 4 to $32 \mu \mathrm{g} / \mathrm{m}^{3}$. Recently reduced $\mathrm{FEV}_{1}$ values were reported in diamond workers who used polishing discs containing Co and who were exposed not only to Co but also to other substances such as iron, silica, and diamond ${ }^{1629}$; mean concentration of Co in air ranged from 0.7 to $42.8 \mu \mathrm{g} / \mathrm{m}^{3}$ (personal sampling).

Acute alveolitis possibly leading to lung fibrosis has also been associated with inhalation of dust containing $\mathrm{Co}$ in the hard metal industry and among diamond polishers. Several authors ${ }^{2} 781630$ have attributed the parenchymal lesion solely to Co. Roto did not find any lung impairment in workers exposed to Co metal powder in a Co refinery in Finland $\left(80-190 \mu \mathrm{g}\right.$ soluble $\left.\mathrm{Co} / \mathrm{m}^{3}\right) .^{20}$ Morgan and Verhamme reported their experience of the health surveillance of workers in plants producing Co oxide, Co salt, and Co metal powder; they never found evidence of an increased risk of lung fibrosis..$^{21} 31$ In our exposed population, there was no indication of pulmonary fibrosis as lung volumes, lung diffusing capacity, serum PC-III-P concentration, and chest radiographs were within normal limits.

These results, together with recent experimental work (see later), lead us to conclude that exposure to Co alone (metal, oxides, or salts) does not cause parenchymal change, contrary to the observations in the hard metal and diamond polishing industries. This discrepancy cannot be simply explained by a lower exposure in Co producing plants; as confirmed during this study, high airborne concentrations of $\mathrm{Co}$ and increased concentrations of $\mathrm{Co}$ in the urine of workers are found in Co refineries. It is also interesting to note that in the cemented tungsten carbide industry, hard metal disease has often been found in grinders who have only ground on sintered (hard) tungsten carbide, an operation generating low air concentrations of $\mathrm{Co}^{2}$ These findings suggest that the role of other constituents and their possible interaction with Co particles must be considered in the pathogenesis of interstitial lung lesions.

This view is supported by recent in vitro and in vivo experimental studies ${ }^{32-35}$ performed in our laboratory which show that the biological reactivity of Co-tungsten carbide mixture is much greater than that of Co metal particles alone. The bioavailability of $\mathrm{Co}$ is also enhanced in the presence of tungsten carbide. For example, a tungsten carbide-Co mixture as prepared by the hard metal industry was almost as toxic towards rat alveolar macrophages as crystalline silica whereas pure tungsten carbide had no effect and pure Co metal powder only slightly impaired cell viability. The uptake of $\mathrm{Co}_{0}$ by macrophages was also increased in the presence of tungsten carbide..$^{32}$ In rats, the intratracheal instillation of a tungsten carbide-Co mixture $(16.67$ $\mathrm{mg} / 100 \mathrm{~g}$ body weight corresponding to $1.0 \mathrm{mg}$ $\mathrm{Co} / 100 \mathrm{~g}$ ) caused a severe alveolitis and fatal pulmonary edema whereas the corresponding dose of Co powder alone only caused a moderate inflammatory response. ${ }^{35}$

Preliminary results also indicate that the delayed fibrotic reaction is only seen after administration of the tungsten carbide Co mixture. The amount of Co excreted in urine was also significantly higher when the animals were exposed to this mixture than to an equivalent amount of pure Co particles, confirming the increased bioavailability of Co metal when combined with tungsten carbide.

These experimental data may explain why parenchymal lesions are rarely, if ever, seen in workers exposed to pure Co dust. The simultaneous inhalation of other compounds such as tungsten carbide seems a necessary condition to induce a severe alveolitis leading to lung fibrosis. This sug- 
gests that acceptable exposure to the metal might have to vary depending on whether exposure is to Co alone or to a combination of $\mathrm{Co}$ and other substances.

We are grateful to Mr A Mallants and Mr C Veriter for their technical assistance. Requests for reprints to: Professor R Lauwerys, Industrial Toxicology and Occupational Medicine Unit, Catholic University of Louvain, 30.54 Clos Chapelle-auxChamps, 1200 Brussels, Belgium.

1 Lauwerys $\mathrm{R}$, Lison $\mathrm{D}$. Health risks associated with cobalt exposure: an overview. Sc Tot Environ 1993 (in press).

2 Sprince N, Chamberlin R, Hales C, Weber A, Kazemi H. Respiratory disease in tungsten carbide production workers. Chest 1984;88:549-56.

3 Kusaka Y, Yokoyama K, Sera Y, Yamamoto S, Sone S, Kyono $\mathbf{H}$. Respiratory diseases in hard metal workers: an occupational hygiene study in a factory. $\mathrm{Br} F$ Ind Med 1986; 43:474-85.

4 Van Cutsem E, Ceuppens J, Lacquet L, Demedts $M$. Combined asthma and alveolitis induced by cobalt in a diamond polisher. Eur $\mathcal{F}$ Resp Dis 1987;70:54-61.

5 Gheysens B, Auwerx J, Van den Eeckhout A, Demedts M. Cobalt-induced bronchial asthma in diamond polishers. Chest 1985;88:740-4.

6 Shirikawa T, Kusaka Y, Fujimura N, Goto S, Kato M, Heki $S$. Occupational asthma from cobalt sensitivity in workers exposed to hard metal dust. Chest 1989;95:29-37.

7 Cugell D, Morgan W, Perkins D, Rubin A. Respiratory effects of cobalt. Arch Intern Med 1990;150:177-83.

8 Hartung M, Schaller K-H, Brand E. On the question of the pathogenic importance of cobalt for hard metal fibrosis of the lung. Int Arch Occup Environ Health 1982;50:53-7.

9 Coates $O$, Watson J. Diffuse interstitial lung disease in tungsten carbide workers. Arch Intern Med 1971;75:709-16.

10 Fischbein A, Luo J-CJ, Solomon SJ, Horowitz S, Hailoo W, Miller A. Clinical findings among hard metal workers. $\mathrm{Br} \mathcal{f}$ Ind Med 1992;49:17-24.

11 Jobs $\mathrm{H}$, Ballhausen $\mathrm{C}$. The medical and technical points of view of metal ceramics as a source of dust. Vertravensarzt Krankkasse 1940;8:142-8.

12 Cullen MR. Respiratory diseases from hard metal exposure. A continuing enigma. Chest 1984;86:513-4.

13 Schepers $\mathrm{G}$. The biological action of particulate cobalt metal. Arch Ind Health 1955;12:127-33.

14 Kerfoot E, Frederick W, Domeier E. Cobalt metal inhalation studies on miniature swine. Am Ind Hyg Assoc f 1975; 36:17-25.

15 Kitamura $\mathbf{H}$, Yoshimura Y, Tozawa T, Koshi K. Effects of cemented tungsten carbide dust on rat lungs following intratracheal injection of saline suspension. Acta Pathol $\Im_{p} n$ 1980;30:241-53.
16 Van den Oever $R$, Roosels $D$, Douwen $M$, Vanderkeel J, Lahaye D. Exposure of diamond polishers to cobalt. Ann Occup Hyg 1990;34:609-14.

17 Meyer-Bisch C, Pham Q, Mur JM, Massin N, Moulin JJ, Teculescu D. Respiratory hazards in hard metal workers: a cross sectional study. Br $\mathcal{f}$ Ind Med 1989;46:30-2-9.

18 Rüttner J, Spycher M, Stolkin I. Inorganic particulates in pneumoconiotic lungs of hard metal grinders. Br f Ind Med 1988;44:657-60.

19 Besch A, Kipling M, Heather J. Hard metal disease. Br f Ind Med 1962;19:239-52.

20 Roto P. Asthma, symptoms of chronic bronchitis and ventilatory capacity among cobalt and zinc production workers. Scand $₹$ Work Environ Health 1980;6:1-49.

21 Morgan L. A study into the health and mortality of men exposed to cobalt and oxides. F Soc Occup Med 1983; 33:181-6.

22 Jones $R$, Mead F. A theoretical and experimental analysis of abnormalities in the estimation of pulmonary diffusing capacity by the single breath method. F Exp Physiol 1961;46:131-43.

23 Jouasset D. Normalisation des épreuves fonctionnelles respiratoires dans les pays de la CECA. Poumon et le Coeur 1960;16:1145-59.

24 Bass $H$. The flow volume loop: normal standards and abnormalities in chronic obstructive pulmonary disease. Chest 1973;63:171-6.

25 Frans A, Veriter C, Brasseur L. Pulmonary diffusing capacity for carbon monoxide in simple coal worker's pneumoconiosis. Bull Physiopathol Resp 1975;11:479-502.

26 Kriss JP, Carnes WH, Ross RT. Hypothyroidism and thyroid hyperplasia in patients treated with cobalt. $\mathscr{f} A M A 1955$; 157:117-21.

27 Prescott E, Netterstrom B, Faber J, Hegedus L, Suadicani P, Christensen JM. Effect of occupational exposure to cobalt blue dyes on the thyroid volume and function of female plate painters. Scand F Work Environ Health 1992;18:101-4.

28 Brewer J. A statistical study of cobalt polycythemia in dogs. Am ₹ Physiol 1940;128:345.

29 Nemery B, Casier P, Roosels D, Lahaye D, Demedts $M$ Survey of cobalt exposure and respiratory health in diamond polishers. Am Rev Respir Dis 1992;145:610-6.

30 Demedts $M$. Case reports: cobalt lung in diamond polishers. Am Rev Respir Dis 1984;130:130-5.

31 Verhamme E. Contribution to the evaluation of the toxicity of cobalt. Cobalt 1973;2:29-32.

32 Lison $D$, Lauwerys $R$. In vitro cytotoxic effects of cobalt containing dusts on mouse peritoneal and rat alveolar macrophages. Environ Res 1990;52:187-98.

33 Lison $D$, Lauwerys $R$. Biological responses of isolated macrophages to cobalt metal and tungsten carbide-cobalt powders. Pharmacol Toxicol 1991;69:282-5.

34 Lison D, Lauwerys R. Study of the mechanism responsible for the elective toxicity of tungsten carbide-cobalt powder toward macrophages. Toxicol Lett 1992;60:203-10.

35 Lasfargue G, Lison D, Lauwerys R. Comparative study of the acute lung toxicity of pure cobalt powder and cobalt-tungsten carbide mixture in the rat. Toxicol Appl Pharmacol 1992;112:41-50.

Accepted 9 November 1992 